\title{
THE INSTITUTIONALISATION OF A NEW SOCIAL POLICY IN THE PORTUGUESE ESTADO NOVO. THE STRUGGLE FOR A CORPORATIST WELFARE (1933-1945)
}

La institucionalizatión de una nueva política social en el Estado Novo portugués: la lucha por un bienestar corporativo (1933-1945)

\author{
ÁLVARO GARRIDO \\ Universidade de Coimbra \\ agarrido@fe.uc.pt
}

Cómo citar/Citation

Garrido, Á. (2020)

The institutionalisation of a new social policy in the Portuguese Estado Novo. The struggle for a corporatist welfare (1933-1945).

Historia y Política, 44, 251-273

doi: https://doi.org/10.18042/hp.44.09

(Recepción: 30/05/2019; evaluación: 02/12/2019; aceptación: 08/05/2020; publicación: 27/11/2020)

\begin{abstract}
This article intents to debate on the goals of the social policy and institutions of fascist regimes. Taking the concept of fascism on a broader scale and not exclusively the Italian fascist experience, this analysis focuses on the Portuguese New State's corporatist regime. Considering that in the interwar context corporatism was a way of building specific and authoritarian social policies, this article puts in evidence the institutional Portuguese structures for welfare and discusses its instrumental goals. Comparing the Portuguese experience with other corporatist systems, was there a corporatist welfare? Was it a new social policy connected to economic modernization and able to compete with the democratic Welfare State? These key-questions are answered by analyzing the contradictions of the Portuguese corporatist welfare system, its lack of universality and non-connection with social rights.
\end{abstract}




\section{Keywords}

Welfare; fascisms; New State, corporatism; Portugal.

\section{Resumen}

Este artículo debate sobre los objetivos de la política social y de las instituciones de los regímenes fascistas. Considerando el concepto de fascismo de forma más amplia y no basado exclusivamente en la experiencia fascista italiana, este análisis se centra en el régimen corporativista del Estado Nuevo portugués. Teniendo en cuenta que en el contexto de entreguerras el corporativismo era una forma de construir políticas sociales específicas y autoritarias, este artículo expone las estructuras institucionales portuguesas para el bienestar y analiza sus objetivos instrumentales. Comparando la experiencia portuguesa con otros sistemas corporativistas, ¿hubo un welfare corporativista? ¿Fue esta una nueva política social conectada a la modernización económica y capaz de competir con el Estado de bienestar democrático? Estas preguntas clave se responden mediante el análisis de las contradicciones del sistema social corporativo portugués de Salazar, su falta de universalidad y su desconexión con los derechos sociales.

\section{Palabras clave}

Bienestar; fascismos; Estado Nuevo; corporativismo; Portugal. 


\section{CONTENTS}

I. INTRODUCTION. II. THE PORTUGUESE ESTADO NOVO. CORPORATISM AND SOCIAL POLICY. III. THE CORPORATIST SYSTEM: SOCIAL CONTROL AND WELFARE. IV. THE NEW SOCIAL PROTECTION SCHEME. IDEAS AND TENSIONS. V. WELFARE CORPORATISM AND ASSISTANCE DEVICES. VI. CONCLUSIONS. BIBLIOGRAPHY.

\section{INTRODUCTION}

The fascist political rhetoric persistently addressed the social issue, very often insinuating a "true Socialism" able to integrate working classes in the nation. To achieve its fundamental goals, the social policy of those authoritarian and totalitarian regimes - Fascisms in a broad sense, as Pierre Milza and other authors called them 1 - hinged on the idea of a "social revolution" capable of mobilizing the masses, governing interests, and restrain the workers' movement ${ }^{2}$.

Despite the differences in the "generic Fascist" regimes that swept across Europe between the two world wars ${ }^{3}$ - except for the persistent Iberian dictatorships of Franco and Salazar, which only fell in the 1970s—, it is clear they all pulled back on the social heritage of demo-liberal welfare states ${ }^{4}$.

To ensure a compulsory social peace, the Fascist regimes have imposed welfare policies mostly based on charity and non-universal social insurances. Those policies were mostly erected in European peripheral dictatorships, where Catholic social thought pervaded corporatist institutions and the authoritarian State devices for the "nationalisation of labour". Italy, Spain, Portugal and the French Vichy's regime were the main examples, join to the Austrian case, where the Chanceller Dollfuss regime was based on the Portuguese Constitution.

South European countries were the most affected by a social-policy approach based on authoritarianism, but it doesn't mean that the corporatist

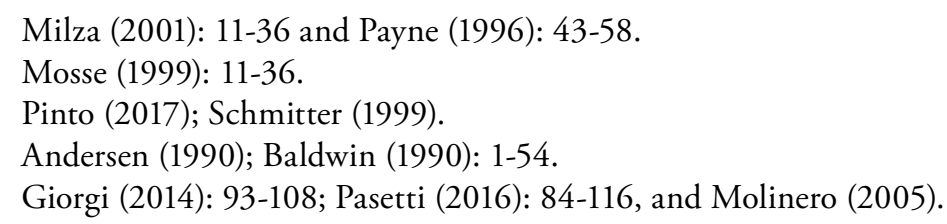


regimes were the main reason for the so-called "Southern model of European welfare" . In south European and south American countries where there were corporatist authoritarian regimes, there was a clear combination of Fascist and social-Christian ideas?. In order to circumscribe labour and leisure, these social policies antagonised both compulsory social security and associative mutualism, as the former was Socialist-inspired and the latter was more popular and "workerist". Between the two world wars, the authoritarian and totalitarian regimes in Europe engaged in a social counter-revolution that involved doing away with trade unionism and driving the economy by the State, thus confirming the evidence that "all Fascisms were corporatist"

The purpose of political-administrative prohibition of free mutualism (it means associative and voluntary), and the repressive surveillance thereof were ancillary to the "nationalisation of labour" and the institutional control of workers sociability.

Before Salazar's dictatorship put in place its vital structures from 1933 onward, the Welfare State was featured by the contrasting ways in which the population could access social justice or minimum social protection: i) the voluntary mutualist movement resulting from the association of craftsmen and workers into mutual aid associations and related organisations; ii) the Catholic or charitable corporatist nannying; iii) the legal and public mandatory insurance, a model which the Republic had instituted in 1919 and which the Republicans themselves began to tear down years later'.

Until the 1914-18 war, mandatory mutual insurance - the social insurance system defined by the State according to a welfare, yet assistance-based logic - had been at the forefront of social policies in many countries. Social economy found its most common practical expression in the combination of mandatory insurance, private commercial insurance and the welfare purpose of mutual associations ${ }^{10}$. Despite the tensions between voluntary association and social protection guaranteed by public laws, Social Economy was more and more ingrained and attached to the role of the State as regulator of social relations. Except for the specificity and sense of autonomy in the cooperative movement, the tendency to nationalise Social Economy was apparent in different liberal European democracies, especially in the early decades of the 1900s. In Portugal, although mutualist organisations and voluntary

Ferrera (1996): 17-37; Katrougalos and Lazaridis (2003): 27-48.

Pinto and Martinho (2008): 40-42.

Manoilesco (1934): 13; Schmitter and Lehmbruch (1979), and Garrido (2018).

9 Pereira (1999): 45-61.

10 Linden (1996): 32-48 and Garrido (2016): 67-111. 
cooperatives acted their part, they nevertheless came up against the inefficiency of Republican institutions and the Dictatorship's wrath against the associationism that followed ${ }^{11}$.

In July 1912, in England, Lloyd George (1863-1945) put through Parliament his National Insurance Act, making provision for occupational diseases and a system of unemployment insurance for factory workers and employees in commerce. The initiative of this British MP and future Prime Minister, a Liberal-Socialist with a legal training background, deeply influenced the Portuguese Republic's legal reform in respect of accidents at work. Despite the strength of mutual societies that had federated under the prestigious Mutualité, France also increasingly accepted the principle of mandatory insurance ${ }^{12}$. Germany, in turn, had long set in place mandatory social insurance against invalidity, old age and accidents at work since the 1880s.

In the early 20th century, besides the theories on the rational administration of the State and the economic interventionism that had been strengthened during the 1st World War, many countries already showed the prevalence of social welfare and solidarity ideas about the legal individualism of the Liberal approach and against the traditional currents that dealt with the "social" issue $^{13}$. Labour relations as a matter regulated through contracts between individuals, or at the initiative of the employers.

The Liberal viewpoint of society did not accept that the social effects of working- class poverty could in any way be prevented and did not recognise the risks associated to the cyclical crisis of the capitalist system. Social insurance, in all its forms, and especially in respect of accidents at work, brought an overall view of society based on the principle of collective solidarity.

Social insurance was regarded as a progressive novelty, since it implied the legal duty of social protection that society itself, as a whole should assume for each individual ${ }^{14}$. Anti-democratic corporatism used the discretionary principle of "national interest" to argue against this Socialist and social-Christian view. Corporatists came forward as a "third way" doctrine and established a patronising and charitable social protection system for "law and order" and "social peace" purposes. To avert the social break-up that threatened modern societies implied having to integrate the "social" issue under an authoritarian moral order and to rebuild the nation within the State.

11 Cardoso and Rocha (2003): 111-135.

12 Gueslin (1998): 145-189.

13 Castel (2012): 455-477.

14 Donzelot (2001): 86-114. 


\section{THE PORTUGUESE ESTADO NOVO. CORPORATISM AND SOCIAL POLICY}

The Portuguese Estado Novo derived the ideology and mechanism of its social policy from corporatism. As a Fascist-type national dictatorship, its desire was to do away with the freedom of association at work and to organise classes and socio-professional groups into organisations supervised by the regime, in addition to setting up social welfare projects most of which were entrusted to private or religious institutions. Not even the academic and socialist version of Social Economy so dear to the dictator ${ }^{15}$-an alternative to the Liberal Social Economy which would allow the State to manage economic and social life- brought any recognition or incentive to associative mutualism and cooperatism.

Being closely linked to the corporatist doctrine and its aim to prohibit freedom of association and union movements, Salazar's social policy resulted in a very specific and rather restrictive idea of Social Economy. Strictly speaking, it condemned associative mutualism and social cooperatism to a long period of oblivion.

As Pedro Teotónio Pereira ${ }^{16}$ pointed out to Salazar and the workers' representatives present in Lisbon, at S. Carlos Theatre on 5 June 1933, "there is nothing we can take from the large foreign welfare systems that can be of use to us; it is too rich for our blood and for our traditions" ${ }^{17}$.

15 As a young teacher at the Faculty of Law of the University of Coimbra, António de Oliveira Salazar taught Economics and Finance and Social Economy. The contents of this course reflected an eclectic mixture of neo-classical ideas, of Krautzian-based legal sociologism of the Catholic and moralist version of Frédéric Le Play's former Social Economy. There is no evidence in the teachings of Salazar of the modern Social Economy proposed by the French solidarist thinkers, particularly Charles Gide and Léon Bourgeois.

16 Pedro Teotónio Pereira (1902-1972). With a degree in Mathematics from the University of Lisbon, Pedro Teotónio Pereira specialised in actuarial calculation in Switzerland. Politically, he was part of the second Lusitano Integralism (Lusitanian Integralism) counter-revolutionary movement, and from 1928 he worked with Salazar in the Ministry of Finance. Between 1933 and 1936, he was Under Secretary of State for Corporations and Social Welfare, thus becoming the main driver of the corporatist system under Portugal's New State (Estado Novo). He continued political endeavours in the corporatist organisation of the economy as Minister of Trade and Industry, between 1936 and 1937. At the end of 1937, he was appointed "special agent" of the Portuguese Government in the Francoist Regime, formed during the Spanish Civil War.

17 Pereira (1937): 57. 
The political architect of the corporatist organisation made it clear that the Estado Novo policy would never yield to a Democratic-based social reformism: "The absurd results of parliamentary democracies that find in social insurance organised by bureaucratic bodies a way to court and seduce the working class clearly show that the State and social method is not feasible", he said ${ }^{18}$.

Given the authoritarian nature of the regime established in the 1933 Constitution -in which the Estado Novo defined itself as a "unitary and corporatist Republic" - and considering the political will to stifle civic freedoms and the working class and petty bourgeois tradition of free mutualism, the social heritage of the Republic was expunged with violence. This former reformist past, whose main work rested in compulsory social insurance and in the short-lived Ministry of Labour, had left a principle of a secular WelfareState which Salazar's dictatorship insisted in curtailing.

In order to take up a corporatist social policy —anti-associative and anti-Democratic by definition, though combining the principles of authoritarian social Catholicism and the experience of Italian Fascism-, the Republic socialist heritage would have to be destroyed vigorously. To legitimise the Estado Novo social policy, propaganda had to be used to vilify social reformism, which, despite its inconsistencies, had managed to embed itself somewhat in society, in part due to the combination of compulsory social insurance and the mutualist movement.

One of the first measures taken in May 1928 by the new Minister of Finance, Oliveira Salazar, was to suspend the application of all 1919 laws concerning social insurance. The anti-Republican and anti-Socialist fury benefitted from the mystic environment around the propaganda that claimed for "healthy finances" and from the right-wing coalition that soon formed around the "new order"19.

For ideological and other more pragmatic reasons, Salazar was eager to take action in social insurance matters. The dictatorship felt that the Republican laws were "nationalising", almost Socialist, because it considered that its application - the actual insurance practice, especially where accidents at work were concerned- raised conflicts of interest with some insurance companies, in particular Fidelidade, which was owned by the Teotónio Pereira family, in that they took the insurance premiums and because the compulsory insurance were contrary to what was a true corporatist system should be.

$18 \quad$ Ibid.: 57-58.

19 Rosas (2012): 74-96. 
The prominent role of Pedro Teotónio Pereira, a young Fascist mathematician with expertise in actuarial calculation, in the building of a corporate framework and the Estado Novo welfare model, was sealed in 1928 when Salazar called him to help revise the articles of association of insurance companies. He remained linked to Companhia Fidelidade until 1933, when he moved from private insurance to corporations and social welfare, where he remained until 1936, working closely with the Government and very closely with Salazar.

The anti-social rhetoric of the dictatorship, which was in fact more anti-Socialist than "anti-social", was disproved when the Portuguese Estado Novo imposed and gave legal status to a vast corporatist organisation of the economy and professions. The social dimension of the corporatist system ${ }^{20}$, whose primary purpose was to repress class struggles, nevertheless needed the help of mutual associations and the ancillary action of charities to provide social assistance.

Pedro Teotónio Pereira commented on this hostile relationship, yet filled with ambiguous expressions, between the corporative State and the free mutualist movement: "Our welfare problems cannot be solved by suggestions from savants or by copying what is being done elsewhere, but rather objectively, seeking to integrate them in the forthcoming corporative movement, making the best use of and fostering all the best features — and there have to be some- in our private initiatives, in our popular mutualism, quite interesting at times" 21 .

The laconic way in which the head of corporations talked of mutual associations might have raise some expectations that they could coexist with the "new order", but did not thwart the intention to condemn them to extinction, or at least to make them residual. According to the doctrine and the corporative system regulations, social welfare and labour organisations (national unions and the Casas do Povo e dos Pescadores [people's houses and fishermen's centres], "social cooperation agencies" taken from the unionist logic) should take the space of free mutualism and trade guilds ${ }^{22}$.

The case of the fishermen was one of the most labour sectors put forward by the Estado Novo. In the "liberal era", those work associations often had brotherhoods and maritime associations. The rhetoric of the Salazar's regime was to build up solidarity organisations (both secular and religious) driven by the corporatist system and balancing organisations devoted to an ideal of Christian cooperation.

\footnotetext{
20 Patriarca (1995): 153-187.

21 Pereira (1937): 59.

22 Garrido (2012): 7-29.
} 
From the government's rhetoric, it appeared that the purpose of institutions that governed labour and corporate organisation as a whole would be one of "social balance" and to "uplift the workers' moral". They would have the effect of opposing the fragility and dispersion of corporate mutual societies, the membership of which was compulsory. The new social institutions would signify the righteous combination of "organic professional representation" and "corporate welfare" contrary to both individualism and class sectarianism.

In a guide published by the National Secretariat for Propaganda in 1944, António Júlio de Castro Fernandes (1903-1975) shed some light on the aims of the corporative system, the "new order", which he regarded as being of the Fascist type: "Corporatism has isolated the unionist phenomenon of Socialism, based on the idea that work is a mission in life, a human attitude, a man's capacity". The former founder of the national-unionist movement, who had joined the Estado Novo in 1933, blatantly stated: "Corporatism has counteracted the sector-specific, monopolistic and internationalist unionism with a national unionism characterised by solidarity among the various production contexts. It has counteracted the virus of the struggle with the principle of a solidarity vaccine [...] National-corporative unionism is the unionism based on many life-shaping factors - it is the realistic unionism" 23 .

These exhortations were as dogmatic as instrumental. The national unions formed after September 1933 were of a formal associative nature only, which was in fact contained in the National Labour Statute and enshrined in the Constitution, more specifically in Chapter III of the National Labour Statute (Estatuto do Trabalho Nacional) and in Article 41st of the Estado Novo Constitution, approved in 1933. Positive assurance was given to exclude any alternatives. The ingenious construction of the corporative system, designed for introducing "social peace" and balance interests, was supposed to do away with and combat other forms of workers' association, as deeply rooted as they may have been, just like secular and religious mutualism. Given its implementation and popularity in the labour urban culture, the creation of mutual societies was strongly repressed ${ }^{24}$.

\section{THE CORPORATIST SYSTEM: SOCIAL CONTROL AND WELFARE}

By instituting a corporatist organisation consisting separately of "primary bodies" of capital and labour — forming a first level of asymmetrical unionism

23 Fernandes (1944): 52-53 [our italic].

24 Garrido (2016): 222-236. 
of social relations-, the State gave those bodies the monopoly to represent the active population. However, the mutualist movement was excluded from this corporate pyramid, being mostly formed by small mutual societies linked to labour culture, there remaining the class associations, whose legal recognition and regulations dated from 1891 . This ostracism, however, did not mean that the State had not granted the mutual associations some social functions ancillary to the modest role of corporate welfare. Where this was the case, owing to the law or to political and administrative pressure, the State took over the role. In fact, the dictatorship's political strategy regarding mutualism (free and associative in its origin and cultural tradition) was ambiguous and sought to avoid pure and simple repression. Most of the old labor associations have disappeared immediately after the creation of the corporatist institutions $^{25}$. By legal disposition, all had to adapt the statutes and submit the composition of the governing bodies to ministerial approval. Much of the repression was administrative. The remainder was conducted by political policy in cases where there was suspicion of clandestine political activity.

This precautionary and violent double discrimination of free association, of a mutualist and cooperative nature, on the one hand, and liberal on the other hand, mainly affected the labour world. From then on, in unofficial terms, there was only "national work" and "patriotic unions". As the typical example of the new work order, national unions were led to cooperate with the State according to anti-Democratic standards, so as to establish the strongly conventioned social relations. Some common practices to which unions and mutual societies were bound included the mandatory approval of union leaders, the prior governmental approval of articles of association and the repressive interference in its legitimate representative bodies.

Here, as in other cases, the repressive effectiveness of the State advocated a minimum degree of originality. The concrete realities of mutual associations and of cooperatism itself (of production and consumption) were flushed out and picked up by the corporative institutionalisation. It was only later that the "Corporative State" relied on them to fulfil some social protection functions and to offset its own weaknesses.

In the 1930s and 1940s, the many speeches that paraphrased the social policy of the "Corporatist State" made no secret of its intention to untie the mutualist movement from any commitments to unions. It is for this reason that mutual societies, the most workerist of mutualist associations, received special attention. The simplest and most common way for invoking the "Republican shambles" and obtaining the credibility of its institutions,

25 Patriarca, 1, (1995): 37-84. 
exposing the fallacy of "social progress" ideas engendered in the previous century was by persistently condemning the 1919 compulsory social insurance model, invariably based on the preambles to the laws and the very reports of the National Labour and Welfare Institute (INTP). The 1919 mandatory social insurance model built by the Republicans was especially ambitious in terms of citizenship, but the practice of insurance modalities were far behind the promises. This reality and the administrative weaknesses in the Ministry of Labor, created in 1916, prevented the benefits from being significant.

Many propaganda documents were drafted aiming to convince the working class and capital instances, economic elites and bureaucrats of the benefits of corporate welfare as the mainstay of the "new order". The gradual and continuous achievements of the Estado Novo opposed the utopia of the Republican social policy based on positivism ideas and some socialist issues.

Pedro Teotónio Pereira's attack on the 1919 system of social insurance condemned the lack of technical bases of this too ambitious system that hardly covered the risks of diseases, invalidity, old age and occupational accidents. The head of Corporations and Social Welfare again condemned the Republican social reformism, recalling the political context in which compulsory social insurance had appeared in Portugal and stating his preference for the Fascist-type of social counter-revolution that had emerged in Portugal at a most opportune time: "There has been a lot of legislation and a kind of popular front, like those anti-Fascist fronts so popular in countries where the leftist bourgeoisie joined hands with Communists. I found tons and tons of documents at the former Institute for Compulsory Social Insurance for the implementation of such reforms, which were nevertheless never implemented" 26 .

Labour and capital were fully integrated within the State in the new system for social relations and welfare management. Promises were made regarding a corporate national economy and a social structure based on century-old balances, wisely construed by a State that had established the nation. The members of the corporatist bodies should contribute to the financing of a compulsory social insurance system, the corporatist welfare system.

In his speech delivered at São Carlos, in 1933, Pedro Teotónio Pereira explained what the "new welfare" should be: "Detached from the idea of a bureaucratic, complacent and passive apparatus, not dealing with the State or with public money - as they are tempting targets for abuses and bad appetites - the worker will now view the welfare organisation of his household as his own work, a result of his sacrifice, responsibility and hope [...]. Having,

26 Pereira (1937): 173 
where possible, a clear professional nature, or engendered in the spirit of mutual societies — of which we already have quite a few worthy examplesthe new welfare institutions will become a flourishing reality" 27.

The ideas announced in connection with the new social security model were no less ambiguous ${ }^{28}$. The Under Secretary of State for Corporations and Social Welfare promised a "comprehensive reform" of the laws on insurance schemes for accidents at work, which was, to a great extent, taken. He gave his word that "one of the first aims of our social action" would be sickness and invalidity benefits to the less privileged classes. He nevertheless warned that this work would have to be done gradually, or on a case by case basis. Pension insurance followed the basic social insurances, culminating in a social welfare system that had as its main priority "to meet the more pressing needs" 29.

\section{THE NEW SOCIAL PROTECTION SCHEME - IDEAS AND TENSIONS}

By opposing the imperatives of collaboration and social harmony to class struggle, so as to ensure the promotion of national production and the new public order, the new social protection scheme did not entail any welfare State notion or system, not even of the welfarism type.

According to the Estado Novo, a social policy to provide a framework for socio-professional groups and economic interests was a priority, but it took no direct responsibility for the social protection system ${ }^{30}$. Its task was to provide the framework and to supervise corporative welfare as part of a corporatism, which it termed "association", stating that it did not wish for it to be "part of the State"

It is interesting to see how the opinion of Socialists and Communists differed in relation to the violent trade union order imposed in September

\footnotetext{
Ibid:: 59-60.

Amaro (2018).

Pereira (1937): 61.

Lucena (1976): 170-177.

31 This dichotomy between theory and the never-ending debate on the more or less "associative" nature of the Portuguese corporatist system — which, in fact, had always been anti-associative- was fed by the very international corporatism theorists on the deviations from the Italian experience. This rhetoric discussion was transposed to the Portuguese doctrinal production, given the fact that the creation of corporations and State evidences of a system that had promised to be "self-organised" had come in late.
} 
1933. On the Socialist side, the imminent end of free unionism triggered a strategy of survival entrenched in the cooperative movement. Class associations were left with the tough dilemma of choosing between "dissolution" and "integration" within national trade unions as imposed by the regime. In 1933, Lisbon alone had some one hundred worker representative associations and numerous professional groups, while more than five hundred were found across the country. Many of these, perhaps even the majority, were led by Socialist militants and leaders.

Communists and anarcho-unionists, under their clandestine trade unions, CIS (Comissäo Intersindical, or Inter-Trade Union Committee in English) and CGT (Confederação Geral do Trabalho, or General Confederation of Labour in English), refused to comply with the laws imposing the corporatisation of workers' unions. Even facing the risk of violent repression, they decided to stage a revolutionary general strike ${ }^{32}$.

The Socialists were quite committed to their reformist ways and refrained from acting outside the law, albeit strongly criticising the 1933 Constitution, the National Labour Statute and the decision on the National Trade Unions. Shortly before the deadline given by the Government to trade associations to convert into inconspicuous nationalist trade unions, the Socialist Alfredo Franco urged the Portuguese working class to support associativism, recalling that "cooperatism had always been one of the points of a triangle on which working life was anchored"33. The Socialist Party Secretary-General's appeal for an economic and educational-type associative cooperation was hardly taken into consideration, but this did not prevent FAO (Federation of Socialist Workers' Associations) from organising and participating in the "unity committee" on 18 January 1934, the outcome of which would be tragic for free unionism.

In the Catholic scope, the Church applauded corporativism and made clear their support to the system. A central idea to the 1930s Portuguese Catholic social thought was the praise of socio-working virtues of Middle Age corporations, an argument to which the corporatist doctrine was more or less receptive. The Catholics rejected class struggle and clearly marked their distance in relation to any form of revolutionary unionism, regarding the collaboration between classes and corporatism in general as an exceptional formula for organising social and economic life. They nevertheless insisted that they should not overstep the boundaries into politics or to comment on how to implement the "corporative order". This was what Pope Pius XI had

32 Patriarca (2000): 34-87.

33 Patriarca (1995): 36. 
preached in the encyclical Quadragesimo Anno, in which he spoke of what Leo XIII had written forty years before, in the letter Rerum Novarum, on the respect for forms of governance.

Confronted with the corporatist laws on the "nationalisation of labour" promulgated in September $1933^{34}$, and referring to the decree that established the National Trade Unions, the Catholic unionists firstly welcomed the blows dealt on Communism and Liberalism. They rejoiced at the possibility of reinstating the corporations, which they regarded as the most genuine organisations in a Christian Social Economy.

The trade unions' reactions prior to the "new order" were very diverse and sometimes tactical. In the early years of corporate institutionalisation, issues related to working hours and the expectation of adopting a "household income" - another model taken from the Belgian Social Catholicism, which was reflected in the "living wage", formulated by various Portuguese corporatists - were a feature of everyday life.

As the Catholic trade union movement created its own experiences and some criticism was voiced, such as when the first "Leuven men" returned to Portugal in $1935^{35}$, some Catholic trade union practices emerged bearing strong resemblances to the cooperative heritage of Social Economy, the most known and noticeable of which appeared in Covilha ${ }^{36}$. In February 1932, the local Catholic Trade Unions formed a consumer cooperative, the "Social Renewal Cooperative", along with other organisations and initiatives that

34 We refer to the National Labour Statute (Estatuto do Trabalho Nacional) approved by Decree-law 23048, of 23 September 1933 and the remaining five diplomas of the corporative organisation that strongly affected this sector and were of clear Fascist inspiration, albeit mitigated by the principles and provisions of Catholic social thought: Decree-law 23 049, on Grémios, guilds or employer corporatist bodies; Decree-law 23 050, on national trade unions; Decree-law 23 051, on the Casas do Povo (rural workers); Decree-law 23 053, establishing the Undersecretariat for Corporations and Social Welfare and the National Labour and Welfare Institute. Some of those corporatist institutions were similar to other social institutions that were built in different fascist regimes. The Portuguese Estatuto do Trabalho Nacional was very similar to the francoist Fuero del Trabajo (1938) and not far from the Italian fascist Carta del Lavoro (1927). See Molinero (2005) and Giorgi (2014).

35 We refer to the priests Francisco Pereira dos Santos, Abel Varzim and Manuel Rocha, who, in Belgium, contacted with the Catholic workers' movement and with the Belgian and French social Catholic academia and intellectuals (Rezola, 1999: 88-93). Salazar always feared that the Leuven social Catholics would contaminate the Portuguese Catholic hierarchy, the social institutions and the believers.

Id. 
were supposed to combine Rochdales' idea of cooperatism with Christian social philanthropy. In the case of Covilhã, the Catholic social movement of wool workers and civil construction encouraged the establishment of religious trade unions. The newspaper Voz dos Trabalhadores, which treated education and instruction as the means towards the integral formation of workers, informed about the social and cooperative activity of these unions. Despite some initial misgivings, the Catholic hierarchy recognised and praised the unionist experience of this mountain city. The Church saw in this example a way to reclaim Catholic technical education to the working classes. In the 1930s, Covilhă's cooperative trade union experience approved and supported by the hierarchy and by the Catholic Service itself boosted the establishment of other Catholic trade unions.

\section{WELFARE CORPORATISM AND ASSISTANCE DEVICES}

There was hardly any mention in the 1933 Constitution of the State's responsibility in matters of welfare and assistance. It was for the "corporative Estado Novo" to only encourage and promote solidarity, welfare, cooperation and mutual assistance institutions (Article 41), stressing that no commitment was made to build a social security system funded by the State. On a precautionary basis, the 1933 Constitution even dropped the Republican idea of "right to public assistance" enshrined in the 1911 Constitution.

The social policy principles resulting from the National Labour Statute, the main diploma of the Portuguese corporative system taken from the Italian Fascist piece of legislation Carta del Lavoro [Charter of Labour], were clearer but merely pragmatic. The Statute was published on 23 September 1933 together with five other decrees that established and regulated the compulsory trade guilds, the National Trade Unions, the People's Houses (Casas do Povo), the Economic Houses (Casas Económicas) and the National Labour and Welfare Institute itself.

Supported by the prudent and gradual approach of the social corporatism policy, the National Labour Statute announced the gradual materialisation of the welfare aims that the State wished to achieve. Employers and trade unions were entrusted with the task of setting up and managing their welfare institutions. The purpose of these small social insurance funds was to protect the workers in situations of sickness, old age and invalidity. In order to bind these bodies to such social security purposes, collective labour contracts had to specify the rules on the requirement for employers and employees to contribute to these funds, which could either take the form of 
agreements, conventions, or contracts, in which the State negotiated with itself.

The general bases of welfare organisation were set out in Law 1884 , of 16 March 1935. The "new welfare", as propaganda termed it, was such an important pillar of the corporate system and a regulating instrument of social relations that it came to be the first law passed by the National Assembly once the regime's Constitution was approved in April 1933.

Welfare institutions could be of four different categories. The $1^{\text {st }}$ category consisted of welfare institutions and of trade unions and the welfare institutions of the Community Centres and Fishermen's Centres. This triad of bodies had in common their corporate labour nature for "professional representation" and "welfare" purposes. The $2^{\text {nd }}$ category consisted of the retirement or welfare funds. The $3^{\text {rd }}$ category consisted of mutual aid associations which, although recognised by law, would be doomed to disappear or to a life of hardship, strictly regulated and monitored by arbitrary procedures. The $4^{\text {th }}$ and last category included the civil service, civil or military welfare institutions, and other State officials and administrative bodies ${ }^{37}$.

Corporatist welfare was intended mainly for workers in commerce, industry and services, a large section of the population and of the petty bourgeoisie who, in theory, was protected against risks of illness, invalidity, old age, death and "involuntary unemployment". Compensations or death grants were not general in nature and the unemployment risk coverage never saw the light of day.

According to the doctrine and the law, welfare institutions of the corporatist system should be autonomous, but membership was mandatory. This principle coincided with the mandatory nature of the organisation of "national labour", although the compulsory nature of social insurance in relation to which the Estado Novo had so criticised the Republic was a rerun. Despite the varying degrees in the vertical labour organisation model adopted by Italian Fascism, the Portuguese Estado Novo took resolute steps to institutionalise labour relations nationwide and State-managed, avoiding pluralist organization and social movements.

The trade union social welfare funds were acclaimed as "the most perfect type of corporatist-type welfare institutions" 38 , perhaps because union funds and pension funds had to be fed by employer and employee contributions. The financial balance of both these funds was based on the legal imperative of strict balance between income and expenditure, replicating the financial

37 Diário do Governo, $1^{\text {st }}$ series, Law number 1884, 16th March 1935.

38 Cartilha do Corporativismo, 1940: 71. 
orthodoxy of State budgets. This sparing management was ensured by the capitalisation of their reserve funds and mathematical funds ${ }^{39}$. The income from member contributions generally covered the benefits to be paid to recipients. This simple method, quite different from any distributive model, allowed the accumulation of large amounts of monies in the coffers of the Union Welfare Funds. The income from the contributions received were invested in term deposits and in treasury bonds, which served to pay the benefits to recipients. For decades, the sums in these funds contrasted with the sparing social benefits actually distributed ${ }^{40}$.

Claimed as a great social policy system to dignify "national labour", corporate welfare also provided for health care. Up to 1946, that role had been the responsibility of the national trade unions. Each trade union operated on their own, according to the protocols signed with hospitals and the diligence of leaders, meaning that the health care provided was usually poor and uncertain. Popular protests and the strikes during the $2^{\text {nd }}$ World War years convinced the Government to unify the system, setting up the Federation of Welfare Funds and Medical-Social Services. The Government set up a national plan for the building of hospitals, to be managed by the Misericórdias [charities]. In 1951, the Medical-Social Services served only 335 thousand beneficiaries; this number increased to 2.6 million in 1965 , a considerable increase but still far from that of 1975, when it reached 7.3 million beneficiaries $^{41}$. Up to 1974, the fishermen had their own health services - the Fishermen Centres health clinics - and rural workers had little or nothing to fall back on, even though the Fishermen's Centres were required to provide them with basic health care.

Soon regulations were put in place to govern the first two types of welfare institutions, since the repressive framework of workers' unions had to be concluded and their members had to be integrated in the "national labour" system. The regulations to govern the Community Centres and Fishermen's Centres welfare institutions took longer to implement.

As for the former, the Government was faced with the strong resistance and indifference of the "interested parties". This is perhaps why the legislators tried to find the best way of establishing the welfare conditions and had to deal with the large number of rural workers, trying to counteract, by force, the "irresponsible spirit" of peasants. In 1940, rural workers were forced to join the Community Centres, which had turned into welfare institutions,

39 Carreira (1996): 55-81.

40 Cardoso and Rocha (2003): 122.

41 Carreira (1999): 184-187. 
assuming the role of social insurance providers. The corporatists, in their doctrinal rhetoric, often called them "rural mutual associations", suggesting that the principle of association therein had remained intact.

In respect of the Fishermen's Centres, although their founding law and regulations both provided for the compulsory requirement - they both date from 1937 and were legislated in a hurry following the strike staged by the cod fisher sector in that same year-, the social, moral and religious assistance they provided was always more put into practice and was more significant than that of welfare ${ }^{42}$. Hence the insistent comparison of the Fishermen's Centre with the old "maritime guilds", religious and mutual welfare societies once common in the Algarve. The few that existed were extinguished to accommodate the Fishermen's Centres.

As regards insurance schemes for accidents at work and occupational diseases, the corporate organisation also meant a step backward. Since these entailed social issues with a strong Republican heritage, the National Labour Statute (Article 49) itself inscribed the principle of protection for victims of occupational accidents and provided for the accountability of employers. The new law governing insurance schemes for accidents at work and occupational diseases was published in July $1936^{43}$, well before the corporate law on labour agreements, and remained in force until 1965.

A propaganda booklet published in 1940 justified the corporate State's options in relation to accidents at work, criticising the Socialist-related legislation which, allegedly, "preferred the economic to the social": "The corporate State solved the problem with a clear understanding of the realities, bringing all cases in which the accident is attributable to the risk of the work itself under the protection of the law" 44 .

In order to justify the meagre compensations provided for in the law and placing liability firmly on the employers, it pointed out that "the burden of insurance fell on the company", even though employers could transfer their liability to the companies also authorised to carry out contracts of insurance against accidents at work. In practice, welfare took on a few cases and dodged as many as it could, on the basis of a breach of liability periods and other irregularities. Since many workers were victims of occupational accidents and diseases and were not protected by labour agreements, and since small companies, of up to five workers, would themselves assume the risk, many labour relations were left unprotected.

42 Garrido (2012): 7-29.

43 Diário do Governo, I st series, Law 1 942, 27th July 1936.

44 Cartilha do Corporativismo (1940): 53-54. 


\section{CONCLUSIONS}

In spite of the doctrinal glorification of corporatist welfare and the idea that it was a new type of social policy, its implementation was slow and full of imbalances, varying according to the social frailty of all work-related aspects, the geographical environment or even the profession and economic activity. The "new welfare" fell short of the doctrinal promises made and proved to be modest in the benefits it actually offered.

A few years after the framework law on corporatist welfare was published, the poor results of the system already sparked controversy over the limited scope of benefits and even over the State's role in the eventual expansion of the system. It was soon confirmed that the Estado Novo had not wanted to invest in social protection and had retreated from banding together capital and labour, as had been promised. Hence the changing nature of the relation maintained with secular mutual associations, in particular the religious ones, which it needed to offset a very poor welfare system and assistance that fell short of the needs to maintain the "social order". Popular and voluntary mutualism was repressed, controlled and transformed. In fact, associative mutualism would never be what it was in Portugal. Although dozens of associations remained under the dictatorship, few were able to preserve the labor culture they previously had and some even collaborated with the dictatorship and the corporatist order.

Even before the War, the corporatist unions' poor welfare results and the effectiveness of the "collective agreements" were questioned by some individuals within the regime. The corporatist triangle, on which the socio-economic order of the Estado Novo was based, revealed tremendous differences between the State, employers and trade unions.

Since many employers refused to comply with the eight-hour working day and were reluctant about the contribution they should pay for the workers' welfare, friction soon sparked in several sectors of the economy. Father Abel Varzim's accusation made at the National Assembly in February 1939 became famous for its critical tone, wherein he stated that national trade unions were not fulfilling their purposes, failed to defend the professional interests of workers, and did not work towards the social balance for which they had been created.

In general, the expansion of the social welfare system created in 1935 was only dealt with during the last years of the regime when, pressured by social movements or due to significant demographic changes, the State hastened to further develop the welfare system and expand the universe of beneficiaries. 
The rate of the active population covered by social security remained very low until the 1970s. In 1960, only $35.6 \%$ of the active population was integrated in the system; ten years later, this increased to $60 \%$. The number of beneficiary pensioners was even lower: only 56 thousand in 1960, having increased to 187 thousand ten years later when rural workers were integrated in the system. With the creation of public Social Security, about 862 thousand pensioners were already covered by this system in 1975 in Portugal ${ }^{45}$.

In the early 1940s, only nine welfare union funds were active, and a little more than one hundred micro Community Centre welfare funds - there were already more than one thousand such centres. In the midst of the War, the State took it upon itself to create new welfare funds for both industry and commerce trade unions and for the rural sector. The population covered by some sort of protection system increased after these interventionist arrangements. Even so, the active population covered by the system (industry, commerce and services) in 1950 accounted for only $37 \%$ of workers.

Social insurance for workers in industry, commerce and services were insignificant, and until 1975 no unemployment risk benefit was ever granted. The initiative taken by Minister Duarte Pacheco in 1932, during the first government with Salazar as President, proposing that the amounts of the Unemployment Fund should be used in the public work programmes of his Ministry was bizarre. Contrary to what the National Labour Statute advocated, unemployment was not included in the series of social risks that should be mitigated by social security, eventually in the form of insurance. The agricultural situation was even more dismal: in 1960, no more than one-fifth of rural workers were covered by the Community Centres' social protection system, which, as a rule, consisted of medical assistance (little or none), sickness benefits and death grants.

In accordance with the base Law on corporate welfare, some child benefits were paid as from 1935 in the form of supplements to salaries. The application of this law was restricted in practice and only at the initiative of very few private companies and conducted by corporate and economic coordination bodies connected to retail trade and the insurance industry. In 1942, child benefits were established for all employed workers in commerce, industry, liberal professions and company managers. In practice, they only benefited some workers and its application scheme was only extended later.

Following the attempts to recover the 1950s corporatism, the Estado Novo social policy brazenly assumed its statist ethos, albeit seeking to make it a modernisation resource. In this connection, a relevant reform of corporatist

45 Carreira (1999): 186. 
welfare was approved in $1962^{46}$, whereby the Ministry of Corporations was given the power to create welfare funds and a Social Council composed of a few ministers was entrusted with the main areas of social policy, including welfare, health and assistance. The more deep-structural measures were designed to bridge the asymmetries between the social benefits granted by the various welfare union funds and to change the funding method. A national and district-wide overall benefit system was set up to this end, according to the social risks in question, thus making way for a mixed funding system of capitalisation and distribution for speeding up the distribution of benefits.

The ineffectiveness of the corporate welfare system and its clear incapacity to uplift the human condition of Portuguese workers soon raised frequent criticism during the $2^{\text {nd }}$ World War, sparked either by the violent strikes against hunger and the cost of living, or by the influence of the 1942 Beveridge plan, which was discussed intensively in Portugal.

In the early 1950s, several voices echoed in Portugal regarding the English welfare state model as a challenge to the State's responsibilities in social protection and in the production of goods and public services, not only as a means to social balance and harmony —as also voiced by corporatists-, but also for social justice redistribution purposes. In other words, to reduce social inequalities due to income imbalances. Those closest to the regime considered the plans of British Labour MPs a mere continuation of the British tradition of social anti-poverty policies, arguing that it would be impossible to replicate Beveridge's audacity because no economy in the world could ever afford it.

Other sectors of public opinion, especially among the opposition and also among those linked to the regime, again called for a new compulsory social insurance system, questioning the lack of direct State responsibilities on matters of social welfare, as since it had become obvious that the corporate organisation would never be able to do so. Articles published in Seara Nova and in Revista de Economia do ISCEF (School of Economic and Financial Sciences) by authors who identified themselves with the social reform plans proposed by William Beveridge to the House of Commons - as requested by Winston Churchill, whose government coalition would be defeated after the War partly because voters entrusted the execution of the plan to Labourdefended the idea of compulsory insurance and State responsibility on matters of social rights ${ }^{47}$.

Naturally, the British vigorous experience of building a modern Welfare State was received as debates were ongoing, albeit limited to the Portuguese

46 Diário do Governo, 1st series, Law 2 115, of 18 June 1962.

47 Amaro (2018). 
State institutions, about the course of action of the social policy followed up till then and about the legal void concerning public assistance issues that the Government had allowed to go on for so long. In these social and economic matters, as in others, the war prompted the legislators to take action.

Ultimately, welfare and assistance were two sides of the same coin; both were designed and regulated to be social order instruments. The analysis of the laws and regulations is in itself enough to prove that the Estado Novo did not have a social welfare policy in place, nor did it have a public assistance system comparable to that before the Republic. The role and meaning of assistance and welfare were blatantly blurred. In agriculture as in fisheries, assistance often took the role that propaganda had assigned to welfare. Although their purpose was of a social welfare nature, they were not of any mutualist nature, since they were not associative nor made risks a social matter.

\section{Bibliography}

Amaro, A. R. (2018). The Late Construction of Portugal Welfare State: The Failure of the Social Corporatist State (1933-1974). Memoria y Civilización, 21, 1-18. Available at: https://doi.org/10.15581/001.21.005.

Andersen, E. (1990). The three worlds of welfare capitalism. Princeton: Princeton University Press.

Baldwin, P. (1990). The Politics of Social Solidarity: Class Bases of the European Welfare State 1875-1975. Cambridge: Cambridge University Press. Available at: https://doi. org/10.1017/CBO9780511586378.

Cardoso, J. L y Rocha, M. M. (2003). Corporativismo e Estado-Providência (1933-1962). Ler História, 45, 111-135.

Carreira, H. M, (1996). Politicas Sociais em Portugal. Lisboa: Gradiva.

Cartilha do Corporativismo (1940). Lisboa: Secretariado de Propaganda Nacional.

Castel, R. (2012). Les métamorphoses de la question sociale. Paris: Gallimard. Available at: https://doi.org/10.3917/vsoc.131.0021.

Donzelot, J. (2001). L'Invention du Social. Paris: Éditions du Seuil.

Gagliardi, A. (2010). Il corporativismo fascista. Bari: Editori Laterza.

Fernandes, C. (1944). Princípios Fundamentais da Organização Corporativa Portuguesa. Lisboa: Editorial Império.

Ferrera, M. (1996). The "Southern Model” of Welfare in Social Europe. Journal of European Social Policy, 6 (1), 17-37. Available at: https://doi.org/10.1177/095892879600600102.

Garrido, Á. (2012), Assistência e Previdência no mar português. A acção social das Casas dos Pescadores (1933-1968). Ler História, 62, 7-29. Available at: https://doi.org/10.4000/ lerhistoria.541.

— (2016). Cooperação e Solidariedade. Uma História da Economia Social. Lisboa: Tinta da China. 
- (2018). Queremos uma Economia Nova! Estado Novo e Corporativismo. Lisboa: Círculo de Leitores; Temas \& Debates.

Giorgi, C. (2014). Le politiche sociali del fascismo. Studi Storici, 1, 93-108.

Gueslin, A. (1998). L'Invention de L'Economie Sociale. Paris: Economica.

Katrougalos, G. y Lazaridis, G. (eds.) (2003). Southern European Welfare States. London: Palgrave Macmillan.

Linden, M. van der (1996). Social Security Mutualism. The Comparative History of Mutual Benefit Societies. Bern: Peter Lang.

Lucena, M. de (1976). O Sistema Corporativo Português. Lisboa: Perspectivas \& Realidades. Manoilesco, M. (1934). Le Siècle du Corporatisme. Paris: Félix Alcan.

Milza, P. (2001). Les Fascismes. Paris: Éditions du Seuil.

Molinero, C. (2005). La captación de las masas. Politica social y propaganda en el régimen franquista. Barcelona: Cátedra.

Mosse, G. (1999). De la Grande Guerre au totalitarisme. La brutalisation des sociétés européennes. Paris: Hachette.

Pasetti, M. (2016). L'Europa corporativa. Una storia transnazionale tra le due guerre mondiali. Bologna: Bononia University Press.

Payne, S. (1996). A History of Fascism, 1914-1945. London: Taylor and Francis.

Patriarca, F. (1995). A Questão Social no Salazarismo, 1930-1947, 2 vols. Lisboa: Imprensa Nacional Casa da Moeda.

Pereria, M. H. (1999). As Origens do Estado Providência em Portugal: as novas fronteiras entre público e privado. Ler História, 37, 45-61.

Pereira, P. T. (1937). A Batalha do Futuro. Organização Corporativa. Lisboa: Livraria Clássica Editora.

Pinto, A. C. (ed.) (2017). Corporatism and Fascism: The Corporatist Wave in Europe. London: Routledge. Available at: https://doi.org/10.4324/9781315388908.

- ; Martinho, F. (orgs.) (2008). O Corporativismo em Português. Estado, Politica e Sociedade no Salazarismo e no Varguismo. Lisboa: Imprensa de Ciências Sociais.

Rezola, M. I. (1999). O Sindicalismo Católico no Estado Novo, 1931-1948. Lisboa: Editorial Estampa.

Rosas, F (2012). Salazar e o Poder. A Arte de Saber Durar. Lisboa: Tinta-da-China.

Schmitter, P. (1999). Portugal: do Autoritarismo à Democracia. Lisboa: Imprensa de Ciências Sociais.

— , Lehmbruch, G. (eds.) (1979). Trends toward Corporatist Intermediation. London: Sage. 